\title{
GENERAL REGULARITIES OF THE DEVELOPMENT PROCESS OF THE HISTORY OF STATE AND LAW ACCORDING TO THE DOCTRINE OF GEORG WILHELM FRIEDRICH HEGEL
}

\section{Oleksandr Holovko}

\section{INTRODUCTION}

Ukrainian historical and legal science has been going through a difficult and contradictory path over the last incomplete three decades from the postSoviet paradigm to broad pluralistic European approaches. The consciousness and methodological tools of a scholar, especially those from the Soviet times, as well as those formed in the traditions of the respective scientific school, were difficult to change. The simplicity and logic of Marxist methodological constructions remained familiar and comprehensible; moreover, they are attractive to new generations of scholars, not only in the history, but also in the theory of law and state, branch legal sciences. It is especially difficult both mentally and rationally for the national science of the history of law and state, to abandon the formative approach to the history of society, which makes the development of state and legal institutions natural and logical.

Absolutized formative approach to the history of law and state has led, in a number of cases, to a kind of "rounding", adapting to its provisions of certain unimpugnable or difficultly rebuttable facts, such as underdevelopment of slavery in the ancient Eastern states (so-called "domestic" or patriarchal slavery), and obviously the same prevalence of this phenomenon in the Old Rus' State, did not interfere to refer the first group to the slave-owning, and the second - to the feudal socio-economic formation. On the other hand, the theory of basis and superstructure defines law and state as secondary phenomena in regard to the socio-economic structure. According to this approach, the study of the most general, universal regularities of the development of law and state as social institutions is beyond the realm of legal reality within its historical dynamics. Hence, there is the desire to periodize the historical and legal process according to the chronology of state entities that existed by changing each other on a certain territory, which nowadays is the territory of really existing state.

Other universal approaches to general regularities of world history of law and state, in particular civilizational, are developed superficially, since the issue of the very existence of such regularities is very difficult from the standpoint of philosophy of law, and philosophy of history. Meanwhile, the solution of the task of searching for the general regularities of the historical 
and legal process requires not just a philosophical and legal, but a historical and legal approach, that is, the analysis of philosophical knowledge about the essence of the history of law and state, its orientation and content. It is important, in this context, to systematically analyze the answers to these largescale and "age-old" questions, provided by the most prominent philosophers of law from the past. The views of prominent German philosophers of the second half of the XVIII - first half of the XIX century occupy a worthy place among them.

The philosophical system created by Georg Wilhelm Friedrich Hegel (1770-1831) is fairly believed as ultimate of German classical philosophy. It is really one of the most versatile and universal. There are few such powerful products of intellectual activity in the New History of mankind that would try to explain and logically order all phenomena of both social medium and human nature, and the natural world in terms of a single system. One may call the names of Kant, Hegel, Spencer, Marx and Engels. At the same time, their titanic efforts have proved that it seems impossible to develop a philosophic system that would be single absolutely perfect and in no aspect irrefutable, not subject to logical and rationalistic critique. There is no sweepingly "the only true" doctrine and it can not be.

However, the critical mind must choose one of these global theories, get acquainted with all others, and apply it in accordance with one's own scientific worldview within the studies, in particular, within the history of law and state. Eventually, the methodology of scientific research, the main "production tool" of a researcher, is precisely formed and drawn in the depths of philosophical knowledge. Addressing to the Hegelian understanding of the history of law and state from this point of view is both relevant and timely and interesting, especially since this issue has not been covered specifically in Ukrainian legal science. Analysis of this problem constitutes the purpose of this research.

\section{Hegel's Views on the Development of Legal Phenomena within Historical Context}

There are few thinkers in the history of humanity, the attitude to whom would be as constant and controversial as to Hegel's scientific heritage, his ideas. The range is incredibly wide - from the acknowledgment of the ultimate in the world philosophical thought (there is no need to list scholars who had similar opinion about the German thinker, their hundreds, if not thousands, in different countries) up to the accusations in scientific fraud (A. Schopenhauer among contemporaries, K. Popper - the century ago). Like in every ideologically and meaningfully textually large and diverse acquisition, some researchers find, as they believe, justification for opposing 
things, as constitutional state and the police state, liberalism and totalitarianism.

Critical and cautious attitude to the Hegel's doctrine dominated in the Soviet scientific tradition, justified by the fact that K.H. Marx the creator of "the only true doctrine" thoroughly and consistently criticised Hegel's philosophy of law ${ }^{1}$. In particular, the founder of Marxism sought to prove that the convergence of the absolute spirit and the absolute mind in the state and legal sphere is Hegel's desire to justify private property and the monarchical system. Marx criticized the legal characteristics of particular societies, such as Ancient Rome and medieval estate society.

It is interesting that Marx, by raising objections against Hegel's philosophical understanding of law and its development, constantly appeals to the concept and content of the state. From his point of view, a man, a family and civil society are the components of the state. He noted that "State purpose" and "State power" in Hegel's philosophy were mystified, when they were declared as certain "ways of existence" of the substance, and they appeared to be detached from their real existence ..."

The collapse of the USSR, the formation of the independent state of Ukraine were accompanied by the transformation of scientific paradigms, in particular in the field of historical and theoretical jurisprudence. The Marxist monism of understanding social history, including the history of law and state (in its rather simplistic, Soviet, "Marxist-Leninist understanding") was replaced by philosophical, worldview and methodological pluralism. That also led to an unbiased view of the ideological opponents of Marxism. Both open access to neo-Hegelian concepts and rethinking of the original sources themselves were of interest. According to M. I. Pyliankevych, "We observe the final development of rationalism in Hegel's philosophy. The higher the desire of rationalism - to liberate oneself from any living content in nature and in the world of people, to reach the final point regarding abstract speculation, to spiritualize the world in the concept - it is completely fulfilled in Hegel's philosophy",3.

Hegel's philosophical and legal views are set out in a large array of his fundamental works. His ideas in concentrated form are contained in the monograph "Fundamentals of the Philosophy of Law or Natural State

\footnotetext{
${ }^{1}$ See: Marx K.H. (1927) K kritike gegelevskoj filosofii prava. Retrieved from: lugovoyk.narod.ru/marx/01/12.htm

${ }^{2}$ Ibid.

${ }^{3}$ Pilinkevich N.I. Istoriya filosofii prava. Filosofiia ta entsyklopediia prava $v$ Universyteti sviatoho Volodymyra: In 2 Vol. Kyiv: Lybid, 2011. Vol. 1. P. 273.
} 


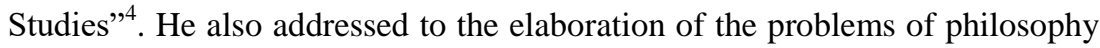
of history. The special work "Philosophy of History" is focused on that problem $^{5}$. It is generally accepted that the philosophical understanding of history by Hegel became the first universal scheme of the historical development of mankind. Hegel occupies a prominent place in the history of philosophical, political and legal thought. His ideas had a significant impact on further spiritual development around the world and gave a powerful impetus to new research in a variety of intellectual fields ${ }^{6}$.

The ideas and conclusions of the thinker also influenced the formation and development of the history of state and law as a science. First of all, he made an attempt to create unified philosophical scheme of history as universal, and secondly, he determined the philosophical content of such phenomena as law and state. All this created the basis for the development of the history of law, not just as a "descriptor" and "re-teller" of legal phenomena and facts, but created its unified concept. Understanding of law and history in terms of Hegel's dialectical philosophical system was extremely important for the development of the history of state and law as a science.

The creative heritage of the philosopher is extremely voluminous and diverse. All his works are intrinsically and substantively interconnected, that is why the philosophical and legal understanding of the history is presented in many of Hegel's works, including not very popular (mostly early ones). In 1798-1802 the young teacher paid great attention to the problems of the state and legal system of Germany. The result was the work of the "Constitution of Germany". "Hegel covered many issues there, including the history of the German Empire and its breakup into separate independent states (principalities, lands, etc.), the current state of affairs with statehood in Germany, the nature of relations between different states, European politics, war, future German state, etc."7. Naturally, the thinker begins his systematic study of the philosophical and legal characteristics of the history of one particular state (it is by ethnic, tribal and legal principle) - the German one. It is clear that he analyzes the regularities of his own homeland.

It is not a surprise that Hegel's main idea is centralistically national - he supports the unification of German state formations in one centralized state, and makes philosophical and legal conclusions and generalizations from historical and legal material from this angle. Herewith, the historical types of

\footnotetext{
${ }^{4}$ Hegel G.W.F. Osnovy filosofii prava abo pryrodne derzhavoznavstvo. Pereklad z nimetskoi R. Osadchuka ta M. Kushnira. K.: Yunivers, 2000.

5 Hegel G.W.F. Filosofiya istorii. Retrieved from: http://books.google.com.ua/books? $\mathrm{hl}=\mathrm{ru} \& \mathrm{id}=\mathrm{i} Y \mathrm{eNCwAAQBJ} \& \mathrm{oi}=\mathrm{fnd} \& \mathrm{pg}=\mathrm{PT}$.

${ }^{6}$ Nersesyants V.S. Filosofiya prava Gegelya. M.: Yurist, 1998. P. 5.

${ }^{7}$ Ibid. P. 15.
} 
public administration, finance, and justice for him in this work seem irrelevant to understanding the concept of the state. Here the philosopher distinguishes two main types of state - centralized in exercising state functions and decentralized.

It is the second type that seems attractive to the author, since according to G.W.F. Hegel it successfully combines the common interest and individual freedom of personality that the thinker, like his predecessors (Kant and Fichte), places at the center of his ethics and in general anthropological, legal, social constructions. The central state power in a decentralized state, gives its citizens freedom in everything that does not relate to the direct purpose of state power ${ }^{8}$.

The author expressed one of the pivotal ideas of his philosophical and legal, philosophical and historical doctrine in the "Constitution of Germany" that the state is the realization and convergence of the spirit in three stages (stages of the state and legal history of mankind):

- Eastern tyranny;

- republic;

- constitutional monarchy with a representative system.

He considered the latter to be German according to national and cultural nature, as the highest and most relevant to the ideas of society, man, his freedom. Hegel also argued that each nation must independently go through own cultural stages, before entering into the universal world correlation ${ }^{9}$. Thus, as we can see, the views of the philosopher coincide with the ideas of his contemporaries, representatives of the German Historical School of Law (see below).

"Historical Essays" (1797-1800) is another early work of Hegel, which is relatively unknown to scientific community. Here he makes a conclusion, interesting till now - about the fact when the social majority (lower class) becomes real actors in the historical and political reality. "... The moments when people behave actively, acquiring subjective qualities, are extremely interesting and important. Apparently, the history rarely offers such opportunities. Hegel calls two such points: the war (or rather, the direct battle) and the revolutionary protest against tyranny" ${ }^{\prime 10}$. That interest of the philosopher about the participation of the masses, social lower class in the creation of the history that mostly interested the Soviet scholars as representatives of orthodox-Marxist philosophy and the history of law.

\footnotetext{
${ }^{8}$ Ibid. P. 17.

${ }^{9}$ Ibid. P. 18-19.

${ }^{10}$ Karimskiy A.M. Filosofiya istorii Gegelya. M.: Izd-vo MGU, 1988 P. 12.
} 
The philosophical and legal views of the thinker are set out in the most holistic form; in the fundamental work "Fundamentals of the Philosophy of Law, or Natural Law and State Studies" (1821). The disclosure of the role and importance of the conceptual apparatus, its historical conditionality has great importance among its provisions for the methodological justification of historical and legal research: "... Every definition in law is dangerous. ... For example, the definition of a human being would be impossible for Roman law, because a slave would not fall under this definition...; the definition of ownership or owner would be also risky for many systems. Dermining the definition often derives from etymology, at least derived from it and abstracted from the specific cases, the basis of which are people's feelings and ideas. The correctness of the definition is determined through the comparison with existing ideas. ... Concepts in themselves and in their truth, and concepts in the imagination can and should differ in form and manner". This meant that historical and legal science had to operate with a clear conceptual apparatus, to have a specific and historical approach to it. Moreover, a similar approach to the concepts and definitions demonstrates the use of understanding of the dialectical interrelation of content and form.

The legal systems, according to Hegel, simultaneously have historical and national conditionality: "The law is generally positive: a) in the form of its validity in a certain state ... b) in content ... because of the special national character of the people, the stage of its historical development and through the interaction of all relations belonging to natural necessity ... Observing the progress and development of legal definitions over time is exlusevely historical task, as well as the study of their influence on thought, manifested in comparison with other legal relations"11. Thus, Hegel, through his dialectical analysis, like no one before, demonstrates the dynamism of historical and legal processes, changes in legal reality over time.

Thus, the philosopher is essentially the first who fully revealed not only the content of concepts, their speculative nature in science, but also the relationship of legal and historical in them. The meaning of Hegel's teachings resulted that the existence of the universal spirit is carried out in the world history in the full extent of its internal and external essence ${ }^{12}$. The law and state as manifestations of this spirit have the development of its manifestations, that is, the history. The national and historical character of law and its conceptual apparatus, according to Hegel's reasoned opinion, had one

11 Hegel G.W.F. Osnovy filosofii prava abo pryrodne derzhavoznavstvo. Pereklad z nimetskoi R. Osadchuka ta M. Kushnira. K.: Yunivers, 2000. P. 19-20.

${ }^{12}$ Pilinkevich N.I. Istoriya filosofii prava. Filosofiia ta entsyklopediia prava $v$ Universyteti sviatoho Volodymyra: In 2 Vol. Kyiv: Lybid, 2011. Vol. 1. P. 302. 
of the greatest manifestations of the spirit and will of the people in classical Roman law.

Here, he uses the findings of the founder of the German law school, G. von Hugo, concerning the studies of the latter on Roman civil law. Moreover, the philosopher, in our opinion, is ahead of time, giving in the analysis of Roman law a prototype of the concept of "living law", which was formed a century later in the writings of E. Ehrlich. This opinion is worded as follows: "... The inconsistency of Roman jurists and praetors should be regarded as one of the greatest advantages that made it possible to retreat from unjust and abhorrent institutions ..."13

However, this true and profound conclusion of the thinker on the importance of law enforcement within legal existence, he did not extend to the case law, without generalizing the importance of law making during law enforcement. In general, specific historical and legal stories sometimes give the thinker very subjective estimates. Thus, Hegel in his later work "Philosophy of the History", gave the following assessment for the English legal system: "In terms of private law, liberty of property, the English people are incredibly behind" $"$.

Hegel also paid attention to the elements of geographical determinism in the historical process. These conclusions, to some extent, have lost their scientific relevance today, although nowadays some scholars continue to share his point of view about the favorable climate of the mankind's civilizational development. "Philosophy of the History" like other Hegel's monographs and textbooks, contains many conclusions that have significant predictive value. Thus, given that the United States of America at the time was relatively sparsely populated, had a large reserve of vacant lands in the West, did not have borders with strong and developed, similar states, he pointed on the ungratefulness of the comparisons between the European states and the United States of America. "As a consequence, America is the country of the future ... those who are tired of the historical museum of ancient Europe are seeking this country" 15 .

But the predictability of Hegel's philosophy of law was not equally effective in all cases. Incidentally, we mention another philosopher's prediction about the state and legal development of mankind, which has not come true, and the beginning of the XXI century stressed it: "Islam having been pushed to Asia and Africa and tolerated in only one corner of the Europe

${ }^{13}$ Hegel G.W.F. Osnovy filosofii prava abo pryrodne derzhavoznavstvo. Pereklad z nimetskoi R. Osadchuka ta M. Kushnira. K.: Yunivers, 2000. P. 24.

${ }^{14}$ Hegel G.W.F. Filosofiya istorii. M.: Sotsekgiz, 1935. P. 421.

${ }^{15}$ Ibid. P. 81. 
due to the rivalry of Christian states, has long left the world historical arena and again returned to the Eastern calm and inviolability"16.

However, we do not analyze Hegel's prognostic achievements in this case, but his approaches to the history of state and law. It is difficult for a scholar to be a predictor, although it is known that K. Popper referred Hegel to the brightest representatives of the "philosophy of the oracles"

\section{Hegel's Dialectics and Historical and Legal Process}

Based on the fundamental positions of philosophical and legal subjectivism and dialectical understanding of both the deontic and the substantive sphere, creating a universal system of explaining the logic of the world's existence and development, Hegel had to be confronted with the issue of the internal regularities of the historical process concerning social, state and legal phenomena. He sought to study, logically derive and explain which engine is the driving force of the development of both law, and its concepts, and its history, and the state, and the human universe in general. On the one hand, "Law is something sacred in general already because it is the being of an absolute concept, of self-conscious freedom"18, and on the other, "Every stage of the development of the idea of freedom has its own law, since it is represented as being of freedom in one of its definitions"19. Thus, we see the development and own vision of the Kantian idea about the ascent to freedom as a sense of the history of law and state.

And the driving force is, of course, Hegel's dialectics: "The moving principle of the concept, not only destroying, but also generating the separation of the common, I call the dialectic... ...The higher dialectic of the concept is to consider the definition not only as a boundary and something opposite, but to generate positive content and positive result from it, which is the reason why it is the development and immanent promotion. Such dialectic is not the external action of subjective thinking, but the very soul of the content, which is the organic basis for its branches and fruits". The possibility of knowing the absolute spirit through its manifestations also means the possibility of knowing the history as the highest form of historical knowledge through the identification of causal relationships and regularities ${ }^{20}$.

\footnotetext{
${ }^{16}$ Ibid. P. 340.

${ }^{17}$ Popper K. Otkrytoye obshchestvo i ego vragi. Per. s angl. pod red. V.N. Sadovskogo. M.: Feniks. Mezhdunarodnyy fond «Kulturnaya initsiativa», 1992. Vol. 2. P. 16-17.

${ }^{18}$ Hegel G.W.F. Osnovy filosofii prava abo pryrodne derzhavoznavstvo. Pereklad z nimetskoi R. Osadchuka ta M. Kushnira. K.: Yunivers, 2000. P. 44.

${ }^{19}$ Ibid. P. 45.

${ }^{20}$ Karimskiy A.M. Filosofiya istorii Gegelya. M.: Izd-vo MGU, 1988 P. 59.
} 
Thus, a large-scale, comprehensive, scientific method of cognition was offered for current and further historical and legal studies, which retains its methodological relevance not only now, but also in the foreseeable future. The dialectical interrelation of legal phenomena and processes in their historical development, their causes, mechanism and direction, was the Hegel's answer to the question about the content and regularities of the history of state and legal institutions.

Moreover, the historical process both has its own regularities, and it is the highest law, but Hegel has observed the world history in indissoluble unity with the history of the state as an institution. We share the point of view of V.S. Nersesiants, who interpreted the thought of the German thinker: "The highest regularity of the history breaks its way through the peculiarities of states, peoples and individuals" ${ }^{\prime 21}$.

The notorious Hegel's triad, the first element of which is being ("being nothing - formation"), was necessarily applied both to law being and the mechanism of its transformation over time. From the point of view of law being, Hegel, in particular, formulated the concept of a combination of law making and law enforcement. In fact, the modern three-level understanding of the law being (law as ideas; law as norms; law as legal relations) is fully set forth in the writings of the German thinker.

He also creates a substantial basis for understanding law as a measure of not only of freedom, but also of human behavior. "An act becomes the expression of will as subjective or moral"22. It also brought the possibility of historical and legal knowledge to a qualitavely new level. The state of human legal consciousness is the determinant of legally significant activity of a person: "However, the law does not work, only the real person acts, and while evaluating human actions, according to this principle, one can talk about how much it has taken this law, how far it has entered into its beliefs" ${ }^{\text {"23 }}$.

In the hierarchy of special rights, constructed by G.W.F. Hegel, the state occupies the highest place, that is, according to V.S. Nersesiants, the most specific law is the state ${ }^{24}$. Thus, the law and state for the German thinker are correlated as more general and more specific - in fact there is a convergence from the concept of abstract law to the state as the most specific law, that is, from general to specific. Thus, methodological prerequisites were formed for the priority of law over the state as the subject of special historical research, and therefore the thinker not only formulated the theory of the rule of law

\footnotetext{
${ }^{21}$ Nersesyants V.S. Filosofiya prava Gegelya. M.: Yurist, 1998. P. 93.

${ }^{22}$ Hegel G.W.F. Osnovy filosofii prava abo pryrodne derzhavoznavstvo. Pereklad z nimetskoi R. Osadchuka ta M. Kushnira. K.: Yunivers, 2000. P. 107.

${ }^{23}$ Ibid. P. 127.

${ }^{24}$ Nersesyants V.S. Filosofiya prava Gegelya. M.: Yurist, 1998. P. 53.
} 
state, but also substantiated the rule of law principle from a philosophical point of view.

In our deep conviction, the Section of "Philosophy of Law", entitled "World History", is primarily concerned about the history of state and law. The history of material production or the arts hardly has a logical extension of the philosophical and legal discourse on the essence and content of law as a social phenomenon. The principal provisions are set forth by the thinker as follows: "... World history is not just a court, which is acted upon by the power of the world spirit, that is, by abstract and the need for a blind fate devoid of the sense, but if the world spirit is the mind in itself and for itself, but being of the mind in the spirit for itself - is knowledge, then the world history - it is necessary development of moments of mind only from the concept of freedom of spirit and, therefore, self-consciousness and freedom of spirit - interpretation and realization of the common spirit" ${ }^{\prime 25}$.

The dialectical development of the absolute spirit is, according to Hegel, the most profound and fundamental content of historical development, above all the changes of state and legal forms. Accordingly, Hegel defines the four basic (initial - as he calls them) principles and the corresponding four world "kingdoms" (roughly the same as what was later called formations or civilizations - depending on the fundamental historiosophical approach).

The content of these four principles can be most fully and accurately expressed in the words of the author:

"This self-consciousness in the first as direct revelation has its principle the image of the substantive spirit as an identity, where the singularity remains immersed in its essence and not justified for itself". The Eastern "kingdom" corresponds to this principle.

"The second principle is the knowledge of this substance spirit and the fact that it is a positive content, realization and being for itself as a living form of this content, a wonderful moral personality". The Greek "kingdom" corresponds to this principle.

"The third principle is intensification in the middle of oneself for being for itself to abstract generality, and thus to infinite opposition in regard to the equally abandoned spirit of objectivity". The Roman "kingdom" corresponds to this principle.

"The principle of the fourth formation is the transformation of this spirit's opposition, which consists in the fact that it perceives its true and concrete essence in its inner life and is at home concealed in objectivity; and since this spirit returned from infinite opposition, it knows own truth both as a thought

25 Hegel G.W.F. Osnovy filosofii prava abo pryrodne derzhavoznavstvo. Pereklad z nimetskoi R. Osadchuka ta M. Kushnira. K.: Yunivers, 2000. P. 292. 
and as a world of legitimate activity, and thus generates it" ${ }^{26}$. The German "world-historical kingdom" corresponds to this principle.

The historical process is a progressive stage development of the mind in the history ${ }^{27}$.

These ideas were developed in the "Philosophy of History" (1830). The scholar's conclusion about three types of historiography is determining for the development of both legal and general historiography:

- original history;

- reflective history;

- philosophical history.

Thus, we have the traditional for Hegel three-staged ascendancy from recording historical, historical and legal facts, descriptive historiography through analytical to philosophical understanding.

Hegel is primarily interested in the world history as the process occurring in the spiritual sphere, the world and historical process occurring reasonably and therefore in accordance with certain regularities. Since these are the regularities of spirit and mind's development, then a person is able to experience them. This requires:

- to find abstract definitions of the spirit's nature;

- to find out the means used by the spirit in order to realize its idea;

- to clarify the form of the complete realization of the spirit in the existing being - the state ${ }^{28}$.

Thus the thinker in the analysis of the world and historical process, like in case of philosophical and legal understanding of legal phenomena, emphasizes on the use of deductive method. He struck a certain blow to the empirical basis of the sciences of history and history of state and law in particular, which traditionally have to deal with facts, that is, single, special. However, this methodological contradiction, in our opinion, is removed, if this provision is applied only to the third of the above types of knowledge, namely the philosophy of history (in this case we can talk about the philosophy in general in the Hegelian sense, including the philosophy of law).

As an idealist, the scholar "ties" the objective history to the subjective one. "... There is no objective history for the centuries or millennia that preceded the historiography and when there were a series of revolutions, migrations, and in the highest degree turbulent changes, because they did not have a subjective history, a historical narrative. ... The considered actions

\footnotetext{
${ }^{26}$ Ibid. P. 205.

27 Hlushchenko H.Yu. Problema zakonomirnostei ystorycheskoho protsessa v fylosofyy Hehelia. Vestnyk Russkoi khrystyanskoi humanytarnoi akademyy. 2015. Vol. 16. Issue 3. P. 194.

${ }^{28}$ See: Hegel G.W.F. Filosofiya istorii. Retrieved from: http://books.google.com.ua/books? hl=ru\&id=iYeNCwAAQBJ\&oi=fnd\&pg=PT.
} 
accompanied by a clear consciousness about them developing the ability and the need to protect them in this form are realized only in the state, where the awareness of laws has been developed" ${ }^{29}$. Thus, the world history in the sense of Hegel is first of all the history of law and state.

Since the primary, pre-legal, and pre-state status of human society is not the object and subject matter of the study of the science of the history of state and law, then the most applicable to it it are Hegel's conclusions. So, according to his philosophy, the sense is the key interpreter of the meaning of the national state. The rational purpose of a man is to live in the state, and if there is no state yet, then there is a requirement of reason for it to be created ${ }^{30}$.

At the same time, a number of Hegel's historiographical provisions appear to be insufficiently substantiated. They include, in particular, the statement that history, like the sun, moves from East to West. By "fitting" the historiographical reality into its system, he sometimes makes very doubtful conclusions as to the present time, for example, that the Ancient Egypt borrowed its civilization, and therefore the law and the state ... in neighboring Ethiopia $^{31}$.

Considering the great popularity of Hegel's doctrine in the intellectual sphere of the Western world of the first half of the XIX century, we believe that such approaches of the great scholar also had their imprint on the science of the history of state and law, especially common at the time. It should be noted that later scholars of Hegel's scientific inheritance also had the question - why did the thinker pay so much attention to the history of the Ancient East, which is the least well-preserved (at least for European scholars)? "... He paid more attention to the East than to the Middle Ages and Modern Times, although he had lack of reliable historiographical material about the East, obviously, he took into account the awareness of listeners about European history issues" 32 .

The thinker pays tribute to the earliest interpretation of the content of the historical process and its periodization on the development of state and legal institutions - to correlate them with age specific features of human life. The first stage is the "childhood" of the history (the Ancient East), there is also "adolescence" within this epoch (it is the Front Asia, the Inter-Rivers and Persia, which are united by the geographical concept "Central Asia" - in the sense of Hegel it is not at all as nowadays Tashkent, Bishkek or Ashgabat). "Youth" - is Ancient Greece. "Maturity" is "... the kingdom of abstract

\footnotetext{
${ }^{29}$ Hegel G.W.F. Filosofiya istorii. M.: Sotsekgiz, 1935. P. 76.

${ }^{30}$ Grishchuk V.K. Filosofsko-pravovaya paradigma otvetstvennosti cheloveka: monograph. Khmelnytsky: Khmelnytsky University of Management and Law, 2015. P. 76.

${ }^{31}$ Hegel G.W.F. Filosofiya istorii. M.: Sotsekgiz, 1935. P. 189.

${ }^{32}$ Karimskiy A.M. Filosofiya istorii Gegelya. M.: Izd-vo MGU, 1988 P. 25.
} 
omnipotence; it is Roman state, the hard work of the age of history's maturity". And then "... there is the fourth moment of the world history: the German state; ... that would correspond to great age. Naturally, great age is a weakness, but the spirit's great age is its full maturity, where it returns to unity, but as a spirit" ${ }^{33}$.

Much attention Hegel paid to the analysis of all four eras ("kingdoms"). In our opinion, this part of his historical and legal research is specifically and historically conditioned. It had a great influence on contemporaries, but, over time, and with the expansion of knowledge of historians in the field of state and law on ancient times, particularly the Ancient East, this influence was significantly diminished. It is worth noting that one of the main sources in the history of Ancient Egypt for him was the work of Herodotus. However, with regard to ancient history, the philosopher provides a high and striking, even for modern historical and legal knowledge, a brief analysis of general regularities and the course of state and legal development of cities - the states of Ancient Greece and Ancient Rome.

Methodologically important is the conclusion that the need for the correspondance of legal system and the state system to public needs, about the possibility of filling the legal form with a completely different, sometimes opposite content. Hegel predicted to some extent the future extreme aspects of positivism: “... The great transition to empire has changed almost nothing in the constitution. Only the people's assembly no longer corresponded to the state of affairs and disappeared. The emperor was princeps senatus, censor, consul, tribune, he combined all these positions ... The Constitution was completely a non-substantive form, which became absolutely lifeless ...."34

The influence of Hegel doctrine on the development of the most important specific historical and legal subjects is not always mentioned today. Its addressing to the highest possible peaks of abstract thinking increased the angle of view on historical and legal issues, strengthened a critical component of the approach to such phenomena as Roman private law ${ }^{35}$, comprehensively studied by Hegel's contemporaries - representatives of the German Historical School of Law, which is going to be discussed further.

Hegel considered his current period - "the German world" as the most perfect from the point of view of realization of the absolute spirit. It refers to both German state and legal entities, and everything created by Germanic tribes, starting from the Goths and the Franks, the Anglians, the Saxons, the

${ }^{33}$ Hegel G.W.F. Filosofiya istorii. M.: Sotsekgiz, 1935. P. 103-104.

${ }^{34}$ Hegel G.W.F. Filosofiya istorii. M.: Sotsekgiz, 1935. P. 298.

${ }^{35}$ Mytiukov K.A. Kurs rymskoho prava. Rymske pravo $v$ Universyteti Sviatoho Volodymyra. In 2 books. Book 1 /Contributors I.S. Hrytsenko, V.A. Korotkyi; under the edition of I.S. Hrytsenko. K.: Lybid, 2010. P. 6. 
Alemans, etc. This epoch has received the most attention regarding the volume of the text. The author has defined the legal characteristics of theocracy, which the scholar did not consider the state in its full sense. At the same time the author has demonstrated the judicial system of the Carolus Magnus Empire, has addressed other historical and legal subjects, relatively private according to the set universal scientific task. He correctly interpreted feudalism as the absence of law in the traditional sense, as the law - the privileges and personal dependence of some feudal lords on others.

"The formation of states begins, while feudalism does not recognize any states" ${ }^{36}$. We believe that it is not the states in the whole as a social institution, but the national states that started to emerge with the advent of Modern Times. The next stage that the thinker considers as the most perfect - is the transition to the hereditary monarchy. There were three ways for that transition:

- the sovereign subordinates his independent vassals, destroys their demesnial ("particular") power and concentrates it in his hands;

- vassals are released from dependence and become sovereigns themselves in their possessions;

- the sovereign joins peacefully (for some reason the author - O.H. focuses his attention on this way) certain possessions to his individual possession.

In particular, Hegel pointed to a particular way of forming the English constitutional monarchy, noting the importance of the "Magna Carta" for the introduction of freedom and democratic values in England, the beginnings of parliamentarism: "...And Cities supported by the Kings against Barons, formed the third state and elected their representatives to the House of Commons"37.

Hegel considered the Reformation as the most significant event of the fourth epoch of the world history, which had a decisive influence on the legal system of modern states. It has assisted the Western world to overcome the lag of the world spirit. “... It is important to transfer all functions, duties and rights of the authority to the state's control that belongs to the state in accordance with its concept... Now, the system of states is objectively formed, and mutual relations between the states are established" ${ }^{38}$.

Hegel's opinion about the revolution was inspired by the success of the Reformation in England, Austria, Germany, Holland and its failure in France. Its content before the Jacobin dictatorship was that: "The real significance was

\footnotetext{
${ }^{36}$ Hegel G.W.F. Filosofiya istorii. M.: Sotsekgiz, 1935. P. 376.

${ }^{37}$ Ibid. P. 379.

${ }^{38}$ Ibid. P. 399-401.
} 
at once provided to the opinion, the concept of law, and the old boards, which were the basis for unfairness could not stand. Thus, a constitution was developed with the thought of law, and henceforth everything had to be based on it" ${ }^{39}$.

As we believe the elements of justification of the monarchical state system existed in Prussia at the time, the desire to give the religious character to the theory of the development of the absolute spirit, the consideration of its historical improvement as the only true theodicy - and many other things had historically conditioned nature and did not facilitate the universal process of improving theoretical and historical grounds of legal science. The history of law and state as a separate scientific specialty was only being formed at that time; it had the form of describing and commenting on state and legal phenomena. The state of that science of those days lagged behind in many aspects, from the great achievements of the philosophical, first of all, philosophical and legal, philosophical and historical system of Hegel. But the methodological basis was modern and for a long time.

\section{CONCLUSIONS}

1. An important contribution of G.W.F. Hegel into the formation of methodological principles and the very field of science of the history of state and law is raising attention to law as a unique social phenomenon, its removal from the shadow of state and political phenomena and institutions. Deep study of the philosophical discourse of law and its social content and significance, the formation of concepts of constitutional state and civil society have determined the way of development of historical and legal science in the world for centuries ahead.

2. The dialectical method, which had been offered by the scholar and thoroughly developed, further became the most heuristically powerful and applicable for the analysis of comprehemsive processes inherent in the history of law and state, finding the causes, sources and directions of its development, its regularities. We believe that the dialectical approach became the most effective basis for the development of the methodology of historical and legal research for the decades and centuries.

3. It is noteworthy that Hegel revealed the unity, orientation and regularity of the world history to the science, on the basis of the Kantian explanation of the historical process, in particular its state and legal component. Such a vision had an impact on the formation of all further concepts of the world (universal) history of law and state, without exaggeration.

\footnotetext{
${ }^{39}$ Ibid. P. 404.
} 


\section{SUMMARY}

The author has studied philosophical and legal views of G.W.F. Hegel in regard to the history of law and state. His universal philosophical system also covered the problems of historical development of state and legal phenomena and processes. Hegel's teaching on forming the modern methodology of historical and legal studies, in particular regarding the application of the dialectical philosophical approach to legal reality played an extremely important role. That made it possible to view the history of law and state as a dynamic process. The scholar offered a holistic conception of the history of law and state in the context of world history as the process of dialectical development of society; noted the role of the formation of a civil society and the rule of law state. Hegel distinguished four stages in the history of law and state: the Eastern (Ancient East), Ancient Greek, Ancient Roman and Germanic (he characterized the modern stage like that). The content of this process is the progressive development of the mind in the history. The thinker constantly and skillfully used specific historical and legal material in presenting his concept of historical process.

\section{REFERENCES}

1. Marx, K.H. (1927). K kritike gegelevskoj filosofii prava [Regarding the criticism of Hegel's philosophy of law]. Retrieved from lugovoyk.narod.ru/marx/01/12.htm [in Russian].

2. Pilinkevich, N.I., Hrytsenko, I.S., \& Korotkyi, V.A. (2011). Istoriya filosofii prava [History of philosophy of law]. Filosofiia ta entsyklopediia prava $v$ Universyteti sviatoho Volodymyra - Phylosophy and Enciclopedy of law in St. Vladimir University (Vols. 1), (pp. 101-306). Kyiv: Lybid. [in Russian].

3. Hegel, G.W.F. (2000). Osnovy filosofii prava abo pryrodne derzhavoznavstvo [Fundamentals of the philosophy of law or natural constitutional law]. (R. Osadchuk, M. Kushnir, Trans). K.: Yunivers [in Ukrainian].

4. Hegel, G.W.F (1935). Filosofiya istorii [Philosophy of the history]. Retrieved from http://books.google.com.ua/books?hl=ru\&id=iYeNCwAAQ BJ\&oi=fnd\&pg=PT [in Russian].

5. Nersesyants, V.S. (1998). Filosofiya prava Gegelya [Hegel's philosophy of law]. M.: Yurist [in Russian].

6. Karimskiy, A.M. (1988). Filosofiya istorii Gegelya [Hegel's philosophy of the history]. M.: Izd-vo MGU [in Russian].

7. Hegel, G.W.F. (1935). Filosofiya istorii [Philosophy of the history]. M.: Sotsekgiz [in Russian]. 
8. Popper, K. (1992). Otkrytoye obshchestvo i ego vragi [Open society and its enemies]. (V. Sadovskiy, Trans). M.: Feniks. Mezhdunarodnyy fond "Kulturnaya initsiativa" [in Russian].

9. Hlushchenko, H.Yu. (2015). Problema zakonomirnostei ystorycheskoho protsessa $\mathrm{v}$ fylosofyy Hehelia [The problem of regularities of the historical process in Hegel's philosophy]. Vestnyk Russkoi khrystyanskoi humanytarnoi akademyy - Bulletin of the Russian Christian Humanitarian Academy, 16 (3), 192-199 [in Russian].

10. Grishchuk, V.K. (2015). Filosofsko-pravovaya paradigma otvetstvennosti cheloveka [Philosophical and legal paradigm of human responsibility]. Khmelnytsky: Khmelnyts. un-t upravleniya i prava [in Russian].

11. Mytiukov, K.A., Hrytsenko, I.S., \& Korotkyi, V.A. (2010). Kurs rymskoho prava [The course of Roman law]. Rymske pravo $v$ Universyteti Sviatoho Volodymyra - Roman law in St. Vladimir University. (Book 1), (pp. 1-94). K.: Lybid [in Russian].

\section{Information about the author: Oleksandr Holovko, Doctor in Law, Professor,} Head of the State and Legal Subjects Department, School of Law of V.N. Karazin Kharkiv National University 4, Svobody Sq., Kharkiv, 61022, Ukraine ORCID ID: orcid.org/0000-0003-1770-9027 